\author{
Hanna Spasowska-Czarny \\ Maria Curie-Skłodowska University in Lublin, Poland \\ ORCID: 0000-0003-4000-5837 \\ hanna.spasowska@umcs.pl
}

\title{
Protection of Animals Living in the Wild ${ }^{*}$
}

\author{
Ochrona zwierząt wolno żyjących
}

\begin{abstract}
Wild animals function in specific ecosystems, contribute to maintaining biological balance and their legal protection dates back to antiquity. Doubts about the legal nature of free-living animals existed long before the principle of dereification appeared in Polish legislation. Judicature took the position that although animals cannot be denied the attribute of material goods, they are not things. Acceptance of such an assumption led to the conclusion that neither the state nor any other entity has the right of ownership to animals. This was justified by the lack of possibility to subject free-living animals to human authority. The problem of legal protection of free-living animals as a part of substantive administrative law has been regulated in a number of acts of international, European and national law. The types and objectives of the protection of free-living animals and the methods of protection of endangered species are diverse.
\end{abstract}

Keywords: legal protection; free-living animals; wild animals; Polish legislation; dereification; protection of endangered species

CORRESPONDENCE ADDRESS: Hanna Spasowska-Czarny, PhD, Assistant Professor, Maria Curie-Skłodowska University (Lublin), Faculty of Law and Administration, Institute of Law, Plac Marii Curie-Skłodowskiej 5, 20-031 Lublin, Poland.

* Publication has been prepared as part of the research project entitled "The Administrative Law Model of Animal Protection", covered by the application registered with the Funding Stream Support system administered by the National Information Processing Institute, as no. 2016/23/D/HS5/01820 and accepted for financing as part of the competition SONATA 12 held by the National Science Centre, Poland, under the decision of the Director of the National Science Centre in Kraków of 16 May 2017 (decision no. DEC-2016/23/D/HS5/01820, agreement no. UMO-2016/23/D/HS5/01820). 


\section{INTRODUCTION}

The goals and contents of the statutory law pertaining to the protection of animals have changed over time and have been shaped in relation to human needs. Originally, the intention to protect selected species of animals stemmed from religious beliefs, ${ }^{1}$ then economic factors became significant. The first orders and prohibitions referred to specific animal species and were aimed at safeguarding the privileges of monarchs who were the owners and users of nature. ${ }^{2}$

The relationship between man and nature and especially the attitude of a human being towards animals have been the object of philosophical and religious deliberations since the dawn of time. Free-living animals providing food for humans played an important role already in prehistoric times, as evidenced by numerous cave paintings all over the world. ${ }^{3}$

Pagans believed that nature was a force dominant over a man so they respected all living creatures. A special status was assigned to the animals whose forms were taken on by gods according to beliefs. ${ }^{4}$ Respect for animals was also connected with the belief in the afterlife and judgement on worldly deeds of a deceased person, including his or her behaviour towards animals. ${ }^{5}$

Moreover, respect for all living creatures is also related to the belief in reincarnation of a human being who can be reborn in the body of an animal, depending on the deeds performed during the lifetime. A human is regarded by the Hindus as a creature equal to animals, unprivileged by gods, who is obliged to live in accord-

${ }^{1}$ For example, see J. Helios, W. Jedlecka, Zwierzęta w głównych religiach świata, [in:] Aspekty prawne, filozoficzne i religijne ochrony roślin i zwierząt - wybrane zagadnienia, eds. J. Helios, W. Jedlecka, A. Ławniczak, Wrocław 2016, pp. 51-72; C. Janik, Status zwierzęcia w głównych systemach religijnych, [in:] Status zwierzęcia. Zagadnienia filozoficzne i prawne, eds. T. Gardocka, A. Gruszczyńska, Torun 2012, pp. 77-104; J. Woleński, Podmiotowość zwierząt w aspekcie filozoficznym, [in:] Status zwierzęcia. Zagadnienia ..., pp. 11-28; L. Bisgould, Animals and the Law, London 2011, pp. 15-54.

${ }^{2}$ King Bolesław the Brave banned hunting for beavers and appointed guards (beaver keepers) to watch over them. See K. Bronowska, Ochrona środowiska w prawodawstwie polskim - rys historyczny, "Ochrona Środowiska. Przegląd" 2002, no. 1, p. 46; P. Listos, M. Dylewska, M. Gryzińska, Rys historyczny prawnych aspektów ochrony weterynaryjnej zwierząt w Polsce, "Przegląd Prawa i Administracji" 2017, no. 108, p. 115. See also W. Radecki, Zarys historii prawnej ochrony przyrody w Polsce, [in:] Prawne formy ochrony przyrody, ed. J. Sommer, Warszawa 1990, p. 12 ff.; A. Samsonowicz, Łowiectwo w Polsce Piastów i Jagiellonów, Wrocław 1991, p. 39 ff.; J. Sobczak, Ochrona zwierzat w prawie karnym, [in:] Status zwierzęcia. Zagadnienia ..., pp. 167-168 and literatue cited therein; M. Raba, Karnoprawna ochrona zwierzat łownych, "Prokuratura i Prawo" 2010, no. 9, pp. 151-152 and literatue cited therein.

${ }^{3}$ E. Sakowicz, Znaczenie zwierzat w religiach świata, "Forum Teologiczne" 2005, vol. 6, p. 24.

${ }_{4}^{4}$ J. Białocerkiewicz, Status prawny zwierzat. Prawa zwierząt czy prawna ochrona zwierzat, Toruń 2005, p. 77.

${ }^{5}$ Ł. Smaga, Ochrona humanitarna zwierzat, Białystok 2010, p. 14. 
ance with the rules of nature. ${ }^{6}$ Similarly to Hinduism, Buddhism also belongs to the cosmocentric religions which identify God with the surrounding world. Hence, the followers of these religions have a positive attitude towards animals, ${ }^{7}$ avoid killing them, respect them and do not make them suffer. ${ }^{8}$ Buddhists perceive life as a unity and each human act to the detriment of a living creature is considered a violation of this unity. ${ }^{9}$ This moral principle (so-called ahinsa) is shared by Buddhism, Hinduism and Jainism alike. ${ }^{10}$

Surah, one of the sacred books of Islam, clearly emphasizes the similarity between animals and humans. Consequently, people are obliged to treat animals fairly and show them compassion. According to Islam, good deeds towards animals are appreciated by Allah, so it is prohibited to starve and torment animals, kill them when it is unnecessary and mutilate them. ${ }^{11}$ The role of man as a representative of God makes a human being obliged to protect all living creatures. ${ }^{12}$

It is difficult to avoid the impression that Judaism is contradictory in its regulations referring to human behaviour towards animals. On the one hand, humane treatment of animals is emphasized, while on the other hand ritual slaughter is acceptable and justified with a possibility to wash away one's sins by passing them onto sacrificial animals. In the Jewish tradition, it is forbidden to hunt animals, organize fights with their participation, castrate them or sever their body parts, ${ }^{13}$ but it is acceptable to use animals to cater for basic needs of a man who has the highest position in the hierarchy of living creatures. ${ }^{14}$

Following the ancient philosophy, Christian thinkers concluded that animals did not have immortal soul and considered them creatures devoid of intellect. In the Middle Ages, these opinions were upheld (see, e.g., Saint Augustine and Saint Thomas Aquinas), although some scholars of that period (e.g., John Chrysostom the Golden-Mouthed - bishop of Constantinople and Saint Frances of Assisi) expressed compassion towards living creatures. ${ }^{15}$ This philosophy definitely influenced modern views, as well. Anthropocentrism was dominant also in the philosophy of I. Kant and R. Descartes. ${ }^{16}$

\footnotetext{
${ }^{6}$ E. Sakowicz, op. cit., p. 33.

7 J. Białocerkiewicz, op. cit., p. 89.

8 Ibidem, p. 90.

9 E. Sakowicz, op. cit., p. 38.

${ }_{10}$ J. Białocerkiewicz, op. cit., p. 90.

${ }^{11}$ Ibidem, p. 81.

12 E. Sakowicz, op. cit., pp. 30-31.

13 Ibidem, pp. 28-29.

14 J. Białocerkiewicz, op. cit., pp. 82-83.

15 Ł. Smaga, op. cit., pp. 22-23.

${ }^{16}$ U. Zarosa, Status moralny zwierząt, Warszawa 2016, p. 25.
} 
The announcement of Darwin's theory of evolution was a breakthrough event. The dispute with the representatives of Christian thought continues to this day but it contributed to the emergence of the philosophical system of animals' rights in 1892, created by H. Salt. ${ }^{17}$ J.-J. Rousseau was also strongly opposed to Cartesianism, ${ }^{18}$ while J. Bentham, the founder of utilitarianism, is considered one of the most outstanding representatives of the animal protection movement. ${ }^{19}$ However, none of them regarded animals as social creatures or felt any emotional bond with them. ${ }^{20}$

It was not until the beginning of the $19^{\text {th }}$ century when the issues related to animals began to be perceived as requiring legal regulations. At that time humanitarianism was born in France and according to this doctrine the highest values are human dignity, brotherhood and equality. The humanitarian attitude demanded respect for people and efforts to spare them suffering. In previous centuries, human life was not highly valued, and if a person's life was not particularly appreciated, the less so the life of an animal, in view of the established conviction about man's superiority to animals. However, as the humanitarian ideas grew in popularity, views referring only to humans were extended to animals. Nowadays, humanitarianism means not only respect for people and alleviation of their suffering, but it applies to all living creatures and provides the axiological foundation for the protection and appropriate treatment of animals. They are entitled to effective protection in every aspect, because they are a part of natural environment and testify to its richness and diversity. Taking care of animals has become not only a legal obligation, but also an ethical imperative. This is reflected in Article 1 of the Polish Act of 21 August 1997 on the protection of animals ${ }^{21}$ which stipulates that "An animal, as a living creature capable of suffering, is not an object. A human owes an animal respect, protection and care". ${ }^{22}$

Doubts as to the legal nature of animals living in the wild had existed for a long time before the dereification principle was introduced in the Polish legislation. According to the opinions expressed in judicial decisions, although animals do possess

${ }_{17}$ Ł. Smaga, op. cit., p. 25; J. Białocerkiewicz, op. cit., p. 21.

18 Ł. Smaga, op. cit., p. 35.

19 Ibidem, p. 34.

20 J. Białocerkiewicz, op. cit., p. 26.

${ }^{21}$ Consolidated text, Journal of Laws 2020, item 638, hereinafter: APA.

${ }^{22}$ The history of legal regulations concerning the humane treatment of animals in Poland dates back to the 1920s. On 22 March 1928 the President of the Republic of Poland issued the Regulation on the protection of animals (Journal of Laws 1932, no. 42, item 417, as amended). In Article 1 the legislator prohibited maltreatment of all domestic and domesticated animals and birds, as well as wild animals and birds, fish, amphibians and insects. See A. Habuda, W. Radecki, Przepisy karne w ustawach o ochronie zwierząt oraz o doświadczeniach na zwierzętach, "Prokuratura i Prawo" 2008, no. 5, p. 21. See also M. Stefaniuk, Environmental Awareness in Polish Society with Respect to Natural Resources and Their Protection (Overview of Survey Research), "Studia Iuridica Lublinensia" 2021, vol. 30(2), pp. 357-379. 
some qualities of material goods, they are not objects. This presumption led to the conclusion that neither a state nor any other entity has the right of ownership of animals living in the wild. This claim was justified with the fact that a wild animal could not be subjected to human control..$^{23}$ The Supreme Court also questioned the classification of wild animals as objects and defined them as "material entities (not objects) not belonging to anyone". ${ }^{24}$ The dispute about the legal nature of animals living in the wild has lost some of its relevance in view of the unequivocal contents of the aforementioned Article 1 (1) APA. However, this regulation did not resolve the essence of the above-mentioned doubts. ${ }^{25}$

\section{RESEARCH METHODS}

The main method used in the article is primarily the legal dogmatic method. It has been used to analyse and assess the legal regulation regarding free-living animal protection in Poland, including the divisions made into types and purposes of conservation of free-living animals and the methods provided for the protection of endangered species and the manner of implementation of the Hunting Law. As an auxiliary tool, the legal theoretical method was used, aimed at the assessment, in the light of the theory of administrative law, area forms of nature protection: national parks, nature reserves, landscape parks, protected landscape areas or Natura 2000 areas, and in cooperation with neighbouring countries also cross-border areas valuable in terms of nature in order to protect them jointly.

\section{Animals living in the wild (wild animals) and the legal basis of their protection}

In accordance with the definition in Article 4 (21) APA, animals living in the wild (wild animals) are non-domesticated animals living in conditions which are independent of man. These can be both native animals living in natural freedom and foreign animals, e.g. migratory species. W. Radecki divides animals living in the wild into game animals, protected species and other wild animals. ${ }^{26}$

${ }^{23}$ M. Goettel, Sytuacja zwierzęcia w prawie cywilnym, Warszawa 2013, pp. 37-39.

24 J.S. Piątowski, [in:] System prawa cywilnego, vol. 2: Prawo własności i inne prawa rzeczowe, ed. J. Ignatowicz, Wrocław 1977, pp. 352-353; S. Grzybowski, [in:] System Prawa Cywilnego, vol. 1: Część ogólna, ed. S. Grzybowski, Wrocław 1985, p. 462.

25 The principles of the juristic concept of an animal are analysed by M. Goettel (op. cit., pp. 41-42).

26 W. Radecki, Ustawy o ochronie zwierzat. Komentarz, Warszawa 2015, p. 31. Ł. Smaga (op. cit., p. 260) points to the fact that feral animals are not wild animals. They cannot be considered non-domesticated, because being feral consists in a change of the living conditions to those independent of man. Hence, they are still domestic or farm animals which have adapted to living at large. 
Wild animals function in specific ecosystems and help sustain biological balance. Legal protection of animals living in the wild dates back to antiquity. The first regulations were in operation as early as ca 2000 B.C., for example in India, Egypt and Babylonia, ${ }^{27}$ whereas the first acts of international law dedicated to the protection of species in Europe included the Convention on the Protection of Forests and Game Birds of $1781^{28}$ and the Joint Declaration for the Protection of Birds Useful to Agriculture, signed on 19 March 1875 by Austria-Hungary and Italy. ${ }^{29}$

The basic documents of international law protecting animals living in the wild include in particular: the Declaration of the United Nations Conference on the Human Environment, adopted in Stockholm on 16 June 1972, ${ }^{30}$ the Convention on International Trade in Endangered Species of Wild Fauna and Flora, drawn up in Washington on 3 March 1973 (supplemented with three Appendices), ${ }^{31}$ and the Convention on the Conservation of Migratory Species of Wild Animals, signed in Bonn on 23 June 1979.32

The Constitution of the Republic of Poland, ${ }^{33}$ enacted in 1997, does not refer directly to the issue of appropriate treatment of animals. However, it does mention the need to protect the environment. The regulations in Article 5 (which contains a statement that the Republic of Poland ensures the protection of natural environment in line with the principle of sustainable development), Article 74 (which indicates in para. 2 that environmental protection is the duty of public authorities, and in para. 4 imposes on public authorities an obligation to support the activities of citizens to protect and improve the quality of the environment) and Article 86 (which imposes on everyone under the rule of the Constitution a duty to take care of the condition of the environment and liability for causing its degradation) stipulate that protection of the environment is an obligation of all citizens and has a universal character. It means that the duties arising from the binding laws should

27 A. Przyborowska-Klimczak, Ochrona przyrody. Studium prawnomiędzynarodowe, Lublin 2004, p. 35 and the literature cited therein; G. Grabowska, Europejskie prawo środowiska, Warszawa 2001, p. 13.

28 A. Przyborowska-Klimczak, op. cit., p. 36. The bilateral agreement was signed by the King of France and the Prince-Bishop of Basel.

29 Joint Declaration for the Protection of Birds Useful to Agriculture, 1875, IPE, vol. 4, p. 1561.

${ }^{30}$ Text in the Polish language in Wybór dokumentów do nauki prawa międzynarodowego, comp. K. Kocot, K. Wolfke, Wrocław-Warszawa 1978, pp. 581-558.

31 Journal of Laws 1991, no. 27, item 112.

32 Journal of Laws 2003, no. 2, item 17. In accordance with the international law regulations, protected species include, e.g., fur seals, salmon, birds, whales, dolphins. See A. Przyborowska-Klimczak, op. cit., pp. 36-40; J. Białocerkiewicz, op. cit., p. $118 \mathrm{ff}$.

${ }^{33}$ Constitution of the Republic of Poland of 2 April 1997 (Journal of Laws 1997, no. 78, item 483, as amended). English translation of the Constitution at: www.sejm.gov.pl/prawo/konst/angielski/ kon1.htm [access: 10.08.2021]. 
be fulfilled by all entities and pertain to all elements constituting the environment, including wild animals. ${ }^{34}$

As a member of the European Union, Poland is bound by the conventions and agreements to which the EU is a party. In the context of the protection of animals living in the wild it is worth mentioning that the European Union, Canada and Russia concluded in 1997 the Agreement on International Humane Trapping Standards which was confirmed by the Council Decision 98/142/EC of 26 January 1998. Furthermore, the EU and Canada and the EU and the United States signed the Agreed Minutes, the first confirmed by the aforementioned Decision and the second by the Council Decision 98/487/EC of 13 July 1998. The Agreement regulates trapping methods and certification of traps with respect to trapping wild terrestrial and semi-aquatic mammals (specified in Annex 1 of the Agreement) in the context of nature management goals, including control of pests, as well as for obtaining fur, skin or meat and capture of mammals to protect them. ${ }^{35}$ Annex 1 determines standards for restraining and killing traps, and enumerates 19 species of animals covered by the Agreement (however, the Agreement can be extended to cover more species). Moreover, the Annex regulates the methods of trap testing and programs of research on standards. Further Annexes (2-4) contain other arrangements related, e.g., to arbitration between the parties and unilateral declaration of signatories. The Minutes, signed by the EU, Canada and the USA, establish bilaterally further detailed standards of animal trapping.

Moreover, it should be noted that the Council Regulation (EEC) no. 3254/91 of 4 November 1991 stipulated that by 1 January 1995 at the latest it would be prohibited in the EU to use leghold traps which were defined as a device designed to restrain or capture an animal by means of jaws which close tightly upon one or more of the animal's limbs, thereby preventing their withdrawal from the trap. Furthermore, the Regulation prohibits the introduction into the Community of pelts and other goods manufactured of certain wild animal species originating in the countries which catch them by means of leghold traps or trapping methods which do not meet the international humane trapping standards. ${ }^{36}$

The issues of the legal protection of animals, which are a part of the substantive administrative law, are regulated in a number of legal acts. ${ }^{37}$ In the context of the

34 J. Ciechanowicz, Aktualne problemy prawa ochrony środowiska w Polsce, "Prawo i Środowisko" 1997 , no. 5 , p. 25.

${ }^{35}$ M. Gabriel-Węglowski, Przestępstwa przeciwko humanitarnej ochronie zwierząt, LEX/el. 2009.

36 Ibidem.

37 A question raised in the doctrine is whether the Animal Protection Act should be treated as lex generalis (general act) or a special act (lex specialis) in relation to the other Acts mentioned below. A. Habuda and W. Radecki (op. cit., p. 21) claim that the Animal Protection Act is a general act. Even though it may be possible to enumerate many examples supporting this thesis, the authors give only 
protection of animals living in the wild, we should mention the Animal Protection Act, the Act of 13 October 1995 - Hunting Law, ${ }^{38}$ the Act of 16 April 2004 on the protection of nature, ${ }^{39}$ the Act of 29 June 2007 on the organization of farm animal breeding and reproduction, ${ }^{40}$ the Act of 22 June 2001 on genetically modified organisms,${ }^{41}$ the Act of 27 April 2001 - Environmental Protection Law, ${ }^{42}$ the Act of 29 January 2004 on the Veterinary Inspection, ${ }^{43}$ the Act of 11 March 2004 on the protection of animal health and on combating infectious diseases of animals,${ }^{44}$ the Act of 18 December 2003 on health facilities for animals, ${ }^{45}$ the Act of 13 April 2007 on preventing and repairing damage to the environment, ${ }^{46}$ the Act of 19 December 2014 on sea fishing, ${ }^{47}$ and the Act of 18 April 1985 on inland fishing. ${ }^{48}$

\section{Types and goals of the protection of animals living in the wild. Methods of the protection of endangered species}

Animals living in the wild, the protection of which is the object of many legal regulations, can be classified under the following three categories of protection and safety: protection of species, functional protection and humane protection.

Protection of species concerns preservation and maintenance of biological diversity. Its goal is to ensure the survival of rare, endemic and endangered species which are threatened with extinction, as well as their habitats and sanctuaries. In order to achieve this goal, protected areas can be created. Within the framework of species protection, animals can be covered by strict protection which excludes human interference completely and permanently, or partial protection which permits reduction in population size and acquisition of specimens. ${ }^{49}$ In general, the objectives of species protection are preservation of species living in the wild, espe-

\footnotetext{
one - if the Fishing Acts regulate angling, we cannot claim that the Animal Protection Act prohibits angling due to suffering inflicted on fish, resulting from the use of a hook. And we should claim so if we presumed that the Animal Protection Act has a detailed character in relation to the Fishing Acts. Similarly J. Helios, W. Jedlecka, Administracyjnoprawne aspekty ochrony zwierząt, [in:] Aspekty prawne, filozoficzne i religijne ochrony..., p. 81 .

38 Journal of Laws 2015, item 2168, hereinafter: the Hunting Law.

39 Journal of Laws 2020, item 55, as amended, hereinafter: NPA.

40 Journal of Laws 2007, no. 133, item 921.

${ }_{41}$ Journal of Laws 2007, no. 36, item 233, as amended.

42 Journal of Laws 2019, item 1396.

43 Journal of Laws 2015, item 1482.

44 Journal of Laws 2014, item 29.

45 Journal of Laws 2015, item 1047.

46 Journal of Laws 2007, no. 75, item 493, as amended.

47 Journal of Laws 2015, item 222.

48 Journal of Laws 2015, item 652.

${ }^{49}$ See Article 46 (1) to (3) NPA; M. Goettel, op. cit., pp. 239-242.
} 
cially rare and endangered species, and maintaining genetic and species diversity. Therefore, it aims to guarantee permanent existence of all species..$^{50}$ Rare species are those whose existence and population size are endangered, as well as relict species which are the remains of a given fauna limited to small populations. On the other hand, endemic species are those which have a major role in the history of particular species and changes of their environment, and are present on limited areas. Moreover, species which are excessively exploited and killed are endangered or facing extinction. ${ }^{51}$ Priority species are endangered species for which, due to their range of occurrence, EU Member States are particularly responsible. ${ }^{52}$

Functional protection of wild animals serves practical purposes connected with obtaining raw material and produce from them. It consists in maintaining animal populations of certain sizes and managing them in a manner which enables fulfillment of human needs..$^{53}$

Humane protection of animals aims to prevent their maltreatment and infliction of pain and suffering on them. It determines man's attitude to living creatures, as well as the way of their treatment and behaviour towards them..$^{54}$

Very intensive, wasteful human activity results in transformation of the natural environment and leads to disturbances in the functioning of ecosystems and irreversible changes..$^{55}$ Due to the constant growth in human population and the development of civilization, people occupy more and more areas which used to be the natural environment of wild animals. In order to be effective, protection of wild animals must be comprehensive - it should combine protection of animal populations with preservation of their places of living which are conducive to their existence. Only coordinated actions will enable maintenance of the ecosystem stability, biological diversity and continuity of species.

Population sizes of many wild animal species in the EU territory are constantly decreasing, which poses a serious threat to the natural environment and biological balance. This pertains especially to wild birds which mostly belong to migratory species. They are recognized by the Member States as the common heritage and their protection is an example of cooperation for sustainable development. The criteria for creation of sanctuaries for bird species threatened with extinction are specified in the so-called Birds Directive, that is the Directive 2009/147/EC of the European Parliament and of the Council of 30 November 2009 on the conservation

${ }^{50}$ E. Mazur, Środowisko przyrodnicze. Zagrożenia, ochrona i kształtowanie, Szczecin 2004, pp. 147-148.

${ }^{51}$ Ł. Smaga, op. cit., pp. 98-99.

${ }_{52}$ Article 5 (1b) NPA.

53 S. Mroczkowski, A. Frieske, Prawna ochrona zwierząt wolno żyjacych, Warszawa 2017, p. 10.

${ }^{54}$ Ibidem.

${ }^{55}$ E.N. Eadie, Understanding Animal Welfare, Berlin-Heidelberg 2012, pp. 19-31. 
of wild birds. ${ }^{56}$ Article 1 of this Directive provides that its aim is the conservation of all species of wild birds naturally occurring in the EU territory.

Very few regulations of the Animal Protection Act pertain to animals living in the wild. Only Article 21 stipulates that wild animals should be granted the conditions for growth and free-living, and it seems that the pursuance of this goal ought to consist in non-interference of man in the life of these animals. ${ }^{57}$ More attention to the protection of species is given in the Nature Protection Act. Pursuant to Article 46 (1) NPA, protection of species includes animals, as well as their habitats ${ }^{58}$ and sanctuaries. ${ }^{59}$

Endangered species can be protected with in-situ or ex-situ methods. In-situ method consists in the protection of species in their natural habitats (it is prohibited to deliberately kill, mutilate and capture wild animals; to transport, acquire, posses, keep and breed them; to deliberately destroy their eggs, young and developmental forms; to destroy habitats and sanctuaries, nests, anthills, burrows, dens, lodges, dams, spawning grounds, winter habitats and others; to take out, posses and store their eggs and blown eggs; to dissect specimens; to sell, purchase, offer for sale, exchange and give them away; to import and export them; to deliberately scare and disturb them; to take them away from their habitats; to move animals born and raised in captivity to natural environment), ${ }^{60}$ while ex-situ method consists in the protection of species outside their habitats. ${ }^{61}$

In-situ protection can be all-year-round or periodic (Article 52 (2) NPA), strict (that is complete and permanent lack of direct human interference in the ecosystem, formations and elements of nature and natural processes, as well as all-year-round protection of species irrespective of their growth stages) or partial (which permits reduction in population sizes and acquisition of specimens or their parts in accordance with the rules set out in Article 54 NPA).

For the purpose of the protection of animals living in the wild, their habitats and sanctuaries, the Minister of Environment specified in the regulation ${ }^{62}$ the species of animals covered by strict and partial protection, including the species which need so-called active protection. ${ }^{63}$ Furthermore, the regulation specifies manners of species protection $(\S 10)$ and prohibitions $(\S 6-9)$.

56 OJ EU L 20/7, 26.01.2010.

57 Ł. Smaga, op. cit., p. 256.

58 See Article 5 (17) to (18) NPA.

59 See: Article 5 (12) NPA.

${ }^{60}$ Article 52 of the Hunting Law.

${ }^{61}$ Article 5 (6) and (7) NPA. Article 47 NPA mentions zoological gardens and gene banks as forms of ex-situ protection.

${ }^{62}$ Regulation of the Minister of Environment of 16 December 2016 on the protection of species (Journal of Laws 2016, item 2183).

${ }^{63}$ Active protection means the use of protective measures to restore the natural condition of ecosystems and elements of nature, or to preserve natural habitats (Article 5 (5) NPA). 
Nature protection institutions undertake actions aimed at saving endangered species of plants, animals and fungi. These actions include: transferring these species to other places, eliminating causes of dangers, ex-situ protection and creating condition for their reproduction. If actual or predicted changes in the environment are or may be dangerous to plants, animals or fungi covered by species protection, the regional director for environmental protection, or the General Director for Environmental Protection in marine areas, is obliged, having consulted the competent regional council for environmental protection and the administrator or owner of the area, to undertake actions aimed at permanent preservation of a species, its habitat or sanctuary, to eliminate causes of dangers and to enhance the protection of its habitat or sanctuary (Article 60 (1) and (2) NPA).

\section{Exploitation and protection of game animals}

Exploitation of game animals is strictly connected with their broadly understood legal protection. Pursuant to Article 1 of the Hunting Law, hunting is one of the elements of environmental protection. The scope of this concept covers both protection of game animals and management of game animal resources in accordance with the principles of ecology, rational agriculture, forestry and fishing. It seems that hunting defined in this way, as an element of environmental protection, established in practice, can fulfill an important role in sustainable development of all elements forming the environment. ${ }^{64}$

Hunting is assigned a number of goals. It should guarantee protection, preservation of diversity and management of populations, as well as safeguarding and shaping the natural environment to improve the living conditions of animals. The minister competent for environment is the supreme authority of government administration with respect to hunting. At the level of a voivodeship, the local government acts on behalf of the minister and implements government administration tasks.

The scope of protection covers game animals which include the species enumerated in the Regulation of the Minister of Environment of 11 March 2005 on the list of game species. ${ }^{65}$ Pursuant to $\S 1$ (1), game animals can be divided into big game (elk, red deer, sika deer, fallow deer, roe deer, wild boar and mouflon) and small game (fox, raccoon dog, badger, pine marten, stone marten, American mink, European polecat, common raccoon, muskrat, brown hare, European rabbit, hazel grouse, pheasant, partridge, greylag goose, bean goose, greater white-fronted goose, mallard, Eurasian teal, common pochard, tufted duck, common wood pigeon, Eurasian woodcock and coot).

\footnotetext{
${ }^{64}$ J. Skrocka, A. Szczepański, Prawo łowieckie. Komentarz, Warszawa 1998, p. 2.
}

65 Journal of Laws 2005, no. 45, item 433. 
Article 2 of the Hunting Law provides that game animals living in the wild, as the national good, are the property of the State Treasury. On the other hand, Article 21 APA stipulates that animals living in the wild are the national good and should be provided with the conditions for growth and free-living, with the exception of those specified in Article 33a (1). The relationship between the scopes of Article 2 of the Hunting Law and Article 21 APA can raise certain doubts. Although the definition of "animals living in the wild (wild animals)" is given in Article 4 (21) APA, no regulation defines the notion of "game animals". Nevertheless, it is possible to specify the scope of this concept on the basis of the regulation of the minister competent for environment, issued pursuant to Article 5 of the Hunting Law.

Thus, it could seem that in the current legal situation the concept of "game animals living in the wild" is a part of a broader notion of "wild animals". R. Mikosz indicates that this relation is disturbed due to Article 16 (1) of the Hunting Law which permits breeding and closed husbandry of pheasant which is a "game animal" ${ }^{66}$ In this case, it cannot be claimed that it is an animal living in the wild. Therefore, it should be assumed that in the case of game animals covered by "breeding and closed husbandry" the rule specified in Article 2 of the Hunting Law is not applicable and the issue of their ownership should be considered on the basis of relevant general rules concerning the ownership of movables. ${ }^{67}$

As mentioned above, Article 2 of the Hunting Law stipulates that game animals living in the wild are the property of the State Treasury. On the other hand, it is not clear who is the owner of other animals living in the wild which are not game animals. These doubts are intensified by the statement in Article 21 APA that these animals "are the national good". It seems that this phrase itself does not contribute to resolution of the ownership issue. Hence, as there is no regulation which would indicate the owner of these animals, it should be assumed that they belong to nobody until they are acquired (appropriated) ${ }^{68}$ This interpretation is indirectly confirmed by Article 2 of the Hunting Law which also regards game animals living in the wild as "the national good" but at the same time clearly indicates their owner.

${ }^{66}$ Breeding and husbandry of game animals are prohibited, except for pheasant and animals regarded as farm animals on the basis of other regulations (Article 16 of the Hunting Law). This pertains, e.g., to foxes bred for the purposes of fur industry.

${ }^{67}$ R. Mikosz, Prawa do przedmiotów materialnych niebędacych rzeczami, [in:] System Prawa Prywatnego, vol. 4: Prawo rzeczowe, ed. E. Gniewek, Warszawa 2007, p. 939 ff.

68 Similarly W. Radecki, Ustawa o ochronie..., p. 59. Cf. M. Bednarek, Mienie. Komentarz do art. 44-55 Kodeksu cywilnego, Warszawa 1997, p. 85; E. Skowrońska-Bocian, Komentarz do Kodeksu cywilnego, Warszawa 2000, p. 126, 188. In this respect, fish and other aquatic organisms are the exception. In accordance with Article 13 (1) of the Act of 20 July 2017 - Water Law (Journal of Laws 2018, item 2268), they are the profits which the water owner is entitled to obtain. It should also be noted that a swarm of bees referred to in Article 182 of the Civil Code is treated in literature either as a collective entity or as a kind of a collection of things. Cf. S. Rudnicki, [in:] Kodeks cywilny. Komentarz, vol. 1, Warszawa 1972, pp. 232-233. 
On the other hand, no provision of the Hunting Law specifies the content of the ownership law vested in the State Treasury pursuant to Article 2 of the Hunting Law. Therefore, it seems indispensable to refer to the model given in Article 140 of the Civil Code, as in the case of water ownership, and acknowledge that the ownership comprises the entitlement to use and administer. At the same time, the scope of these entitlements has been shaped in a special way. In fact, "administration of game resources", which is an element of hunting (game management), is subject to very detailed legal restrictions, and the rights granted are typically accompanied by responsibilities. The latter pertains especially to various actions aimed at the protection of game animals. ${ }^{69}$

The right to acquire game animals seems to be a significant entitlement constituting the attribute of "using". Many important conditions have to be fulfilled in order to exercise this right, which is clearly visible with respect to hunting. ${ }^{70}$ Similarly, the attribute of "administering" the ownership of game animals living in the wild is subject to major restrictions resulting from the Hunting Law. De lege lata, this administration can, in principle, consist only in lease of hunting areas ${ }^{71}$ or establishment of the management of such areas.

Game animals are legally acquired as a result of hunting conducted in accordance with the binding regulations. Hence, hunting is a sum of activities permitted by law, aimed at acquiring game animals. ${ }^{72}$ Hunting permits can be issued as basic, selective or falconer's. ${ }^{73}$ Pursuant to Article $46 \mathrm{~d}$ of the Hunting Law, shooting of male elk, red deer, fallow deer, roe deer and mouflon is subject to evaluation of compliance with the rules of specimen selection. ${ }^{74}$

It would seem that killing an animal during a hunt is one of the most humane ways: it is done by surprise, with an accurate and effective shot. Nevertheless, the

${ }^{69}$ R. Mikosz, op. cit., p. 941.

${ }^{70} \mathrm{Cf}$. Article $42 \mathrm{ff}$. of the Hunting Law and the Regulation of the Minister of Environment of 27 December 2005 on hunting permits (Journal of Laws 2004, no. 264, item 2209). See S. Stec, Prawo wykonywania polowania, "Przegląd Ustawodawstwa Gospodarczego" 1997, no. 10, p. 25 ff.

71 Cf. W. Radecki, Prawo łowieckie. Komentarz, Warszawa 2005, p. 91 ff.; R. Stec, Tworzenie obwodów towieckich. Podstawy prawne, "Przegląd Ustawodawstwa Gospodarczego" 2000, no. 10, p. 22 ff.; J. Szachułowicz, Problematyka prawna dzierżawy obwodów towieckich, "Przegląd Sądowy" 2002 , no. 4 , p. $47 \mathrm{ff}$.

72 S. Mroczkowski, A. Frieske, op. cit., p. 127. Pursuant to Article 4 (2) of the Hunting Law, hunting comprises tracking, shooting with hunting shotguns, capturing living game animals in permitted ways, and capturing with birds of prey.

${ }^{73}$ See Regulation of the Minister of Environment of 18 April 2005 on the conditions and mode of issuing permits for game hunting with birds of prey (Journal of Laws 2005, no. 69, item 621).

${ }^{74}$ The tasks of the Polish Hunting Association include setting the directions and principles of hunting development, as well as the rules of population and specimen selection (Article 34 (4) of the Hunting Law). 
analysis of shot classification ${ }^{75}$ makes us consider whether the regulation of wild animal populations should perhaps be entrusted to foresters who act more effectively. The inhumanity of killing results primarily from prolongation of dying. ${ }^{76}$ S. Godlewski points to the fact that an animal wounded with a hunter's bullet often can neither stay alive nor die quickly. On the one hand, such killing of a wild animal is permitted on account of the subject, but seems to be unlawful due to the inhumane behaviour of a hunter (Article 6 (1) APA). ${ }^{77}$

Separate regulations pertain to acquisition of animals living in the wild (wild animals) for dissection of their carcasses. Such acquisition requires a permit from voivodeship marshal competent for the place where exhibits are prepared. The marshal issues such a permit on condition that the carcasses are dissected for scientific or educational purposes. After obtaining the opinion of the starost competent for the place where animals are acquired, the permit specifies the conditions and manner of acquiring animals for the above-mentioned purposes. Permits are not issued and the issued permits are withdrawn if there is a justified need to protect genetic resources or there are sanitary reasons. Similarly, acquisition of animals living in the wild for the purpose of creating a collection of their dissected carcasses requires consent of the voivodeship marshal competent for the place of creating the collection. ${ }^{78}$

Pursuant to Article 9 of the Hunting Law, protection of animals comprises creating conditions for their secure life, in particular: combating poaching and all harmful hunting phenomena; a prohibition (except for hunting and trapping) ${ }^{79}$ to scare, capture, posses, injure and kill animals; a prohibition to take out their eggs, destroy dens, burrows and nests.

Combating poaching is a form of mandatory protection of animals living in the wild.$^{80}$ Poaching is an act aimed at acquisition of an animal in an illegal way. ${ }^{81}$

75 S. Godlewski, Vademecum myśliwego, Warszawa 1955, pp. 186-229. The author lists, e.g., shot under the spine, liver shot, stomach shot, kidney shot and leg shot (including birds). The descriptions of wounds indicate beyond doubt that injured animals suffer a lot.

${ }^{76}$ See T. Matecki, Ochrona zwierzat w Polsce, Warszawa 1949, p. 84. The author points out that from the humane point of view a situation when a hunter's shoot is not "clean" (accurate) and an animal does not die immediately is "intolerable". He notes that there are many hunters who will never become skilled in shooting and demands that "such shooters should be eliminated from the group of members and not allowed to hunt".

77 Similarly G. Rejman, Ochrona prawna zwierząt, „Studia Iuridica” 2006, vol. 46, p. 265.

78 Article 22 (4) to (4a) and Article 13 APA.

${ }^{79}$ Hunting periods for particular species of game animals are specified in the Regulation of the Minister of Environment of 16 March 2005 on the establishment of hunting periods for game animals (Journal of Laws 2005, no. 48, item 459) and the Regulation of the Minister of Environment of 1 August 2017 amending the regulation on the establishment of hunting periods for game animals (Journal of Laws 2017, item 1487).

80 Ł. Smaga, op. cit., p. 254.

${ }^{81}$ Poaching comprises primarily snaring and trapping. Snaring consists in capturing an animal with a loop of wire, string or a cord made of steel or synthetic fiber. Snaring is a method of killing 
Article 52 (1) of the Hunting Law penalizes gathering, possessing, producing, storing and offering for sale tools and devices intended for poaching. It is a crime irrespective of fact whether these tools and devices have been used or not. If the perpetrator has already used the devices for poaching, he or she is liable on the basis of Article 52 (5) of the Hunting Law which provides for a more severe penalty. Whoever supplies another person with such tools is liable for aiding and abetting. ${ }^{82}$

There are exceptions to the prohibition on scaring, capturing, possessing, injuring and killing animals. These exceptions comprise hunting, trapping, testing the work of hunting dogs and training of birds used in falconry, as well as special cases permitted by the starost (Article 9 (2) and (3) of the Hunting Law). Protection of game animals includes also actions which should be undertaken primarily by administrators and leaseholders of hunting areas. These actions include, e.g., feeding animals, creating shelters for them, maintaining ecological corridors, and notifying about disease symptoms (Article 11 to 14 of the Hunting Law).

The protection of game animals is only a part of the matters regulated by the provisions of the Hunting Law. They also pertain to the issue of so-called game management which consists in human interference in the population size of wild animals, mostly by means of reduction shooting during a hunt..$^{83}$ Apart from hunting, the basic restrictive and protective institutions provided for by the Hunting Law include, i.a., hunting areas and plans, animal breeding centres and the Hunting Guard. Game management is conducted in hunting areas by leaseholders or administrators. The rationale for the duty of hunting area leaseholders and administrators to employ hunting guards whose task would be to protect animals and conduct game management is questioned by J. Skrocka and A. Szczepański. In particular, their doubts concern the notion of "employment". ${ }^{84}$

\section{Protection of aquatic animals}

The rules of humane protection pertain to all forms of using and exploiting animals living in the wild. Compliance with these rules is of enormous significance also to performing experiments on animals and using wild animals for entertainment purposes.

mainly wild board, roe deer and hare, while trapping is used for birds, including pheasant and partridge. Poaching is also practised to kill aquatic animals. See G. Rejman, op. cit., pp. $266 \mathrm{ff}$.

${ }^{82}$ M. Raba, op. cit., p. 160.

83 Ł. Smaga, op. cit., pp. 255-256. The author claims that functional protection of animals in its current shape is outdated and does not fulfil its goals. The author points out the dominance of the economic factor in shaping game management and archaic methods of its implementation. He calls for total restructuring of the game protection system.

${ }^{84}$ J. Skrocka, A. Szczepański, op. cit. 
Along with animals covered by species protection and game animals, wild animals living in water are also guaranteed protection in separate regulations. In this respect, apart from the Nature Protection Act, we should mention the Water Law (ownership of water, fish breeding in a fish farm), the Environmental Protection Law, and the Act on Inland Fishing which specifies in particular the rules and conditions of protection, breeding, husbandry and catching fish and other aquatic animals in surface inland water. Some of these organisms belong to the category of animals living in the wild, and some belong to the type of farm animals.

The legal character of aquatic animals is complicated. This results from changes in the legal status and the quite complex legal regime of water. M. Goettel considers aquatic animals neither objects nor independent material entities which are not objects. ${ }^{85}$

The Inland Fishing Act regulates, e.g., the issues connected with angling and provides the legal basis for the functioning of the State Fishing Guard and the community fishing guard. It specifies the rules of rational fishing management, including preservation of fish in biological balance (Article 6 (2) of the Inland Fishing Act). Similar protective solutions are contained in the Sea Fishing Act which primarily pertains to the rules of fishing for marine organisms, including the protection of living resources of the sea. ${ }^{86}$ The Act is intended to ensure economically viable commercial fishing, ${ }^{87}$ which consists not only in the acquisition of marine resources but also their protection (e.g., by means of fishing quota, minimum landing sizes, protection periods, a number of orders and prohibitions concerning the time and manner of fishing and restrictions on fishing).

In connection with the fact that fish live in their natural environment until they are caught, protection of these animals is limited to combating poaching and in this form corresponds also to humane protection. ${ }^{88}$

${ }^{85}$ M. Goettel, op. cit., pp. 39-40. See also J. Miłkowska, Status prawny ryb wód śródladowych a status prawny zwierząt łownych, "Ochrona Środowiska. Prawo i Polityka” 2008, no. 1, p. 24.

${ }^{86}$ M. Goettel, op. cit., p. 245.

87 Pursuant to Article 2 (1) (21) of the Sea Fishing Act, sea fishing can be divided into commercial fishing, recreational fishing, fishing for marine organisms for the purpose of scientific research, development works or sea fishing education, as well as restocking, breeding and husbandry of marine organisms.

${ }^{88}$ Ł. Smaga, op. cit., p. 258. 


\section{CONCLUSION}

Protection of animals living in the wild is supported by the establishment of spatial forms of environmental protection: national parks, ${ }^{89}$ nature reserves,${ }^{90}$ landscape parks ${ }^{91}$ protected landscape areas, ${ }^{92}$ Natura 2000 areas,${ }^{93}$ and - in cooperation with the neighbouring states - also border areas with natural values for the purpose of their joint preservation..$^{94}$ Moreover, protection can be carried out effectively also in smaller forms, such as natural monuments, ${ }^{95}$ documentation sites, ecological lands, and nature and landscape complexes. With respect to the latter forms, the legislator provides for the establishment of prohibitions from Article 45 (1) NPA, concerning e.g. deliberate killing of animals living in the wild, destroying their burrows, dens, spawning grounds and spawn. The goals of animal protection can also be achieved by creating zoological gardens and animal rehabilitation centres.

In order to provide animals with spatial and species protection, spatial planning documents should take into account environmental protection issues. ${ }^{96}$ It seems that

89 For example, see D. Danecka, Wybrane problemy funkcjonowania parków narodowych w Polsce, "Przegląd Prawa Ochrony Środowiska" 2015, no. 3, pp. 127-149; A. Habuda, Konsekwencje prawne objęcia parku narodowego obszarem Natura 2000, [in:] Prawne aspekty gospodarowania zasobami środowiska. Korzystanie z zasobów środowiska, eds. B. Rakoczy, M. Szalewska, K. Karpus, Toruń 2014, pp. 155-168; W. Radecki, Ochrona prawna parków narodowych przed zagrożeniami zewnętrznymi (na kilku przykładach z Ojcowskiego Parku Narodowego), "Prace i Materiały Muzeum im. Prof. Władysława Szafera w Prądniku” 2007, no. 17, pp. 21-32; K. Gruszecki, Komentarz do ustawy o ochronie przyrody, Warszawa 2005, p. 40.

90 Article 13 NPA.

${ }^{91}$ D. Lebowa, Podstawy prawne funkcjonowania parków krajobrazowych w Polsce, [in:] Administracja publiczna - człowiek a ochrona środowiska. Zagadnienia społeczno-prawne, eds. M. Górski, J. Bucińska, M. Niedziółka, R. Stec, D. Strus, Warszawa 2011, pp. 185-186; J. Stelmasiak, D. Lebowa, Obszar specjalny w prawie ochrony przyrody - zagadnienia ogólne, [in:] Prawo ochrony przyrody. Stan obecny, problemy, perspektywy, eds. D. Kopeć, N. Ratajczyk, Łódź 2008, pp. 109-114.

92 Article 23 NPA.

93 Areas established on the basis of the Directive 2009/147/EC of the European Parliament and of the Council of 30 November 2009 on the conservation of wild birds (this Directive replaced the Council Directive 79/409/EEC of 2 April 1979 on the conservation of wild birds, OJ EU L 103/1, 2.04.1979) and Council Directive 92/43/EEC of 21 May 1992 on the conservation of natural habitats and of wild fauna and flora (OJ EU L 206/7, 22.07.1992). For example, see A. Habuda, Wyznaczanie obszarów Natura 2000, [in:] idem, Obszary Natura 2000 w prawie polskim, Warszawa 2013, p. 39 ff.

${ }^{94}$ K. Gruszecki, Ustawa o ochronie przyrody. Komentarz, Warszawa 2010, p. 33.

${ }^{95}$ K Sobieraj, Administrowanie formami ochrony przyrody, "Roczniki Nauk Prawnych KUL" 2013, vol. 23(4), p. 150; E. Symonides, Ochrona przyrody, Warszawa 2008, p. 530.

${ }^{96}$ For example, see M. Pchałek, Ochrona gatunkowa w procesie inwestycyjnym, [in:] Wybrane problemy prawa ochrony środowiska, eds. B. Rakoczy, M. Pchałek, Warszawa 2010, p. 131; A. Ciszewska, Zachowanie terenów cennych przyrodniczo w ksztattowaniu struktury krajobrazu na poziomie miejscowego planu zagospodarowania przestrzennego, "Problemy Ekologii Krajobrazu" 2008, vol. 21, p. 239 and the literature cited therein; A. Bołtromiuk, M. Kłodziński, Polityka rozwoju obszarów cennych przyrodniczo, [in:] Rozwój obszarów wiejskich w Polsce. Diagnozy, strategie, kon- 
factors connected with the impact of spatial planning on the environment can be evaluated best and quite objectively at the local (municipal) level. ${ }^{97}$

Protection of all animals living in the wild can be limited. Pursuant to Article 33a (1) APA, in the event when animals pose an extraordinary threat to human life, health or economy, including game management, it is permitted to take actions aimed at reduction in population size of these animals. It can happen when balance is upset by a significant increase in population of a particular species, which represents a threat to certain values. It should be remembered that wild animals used to pose a greater threat to people and farm animals but today this danger is negligible. ${ }^{98}$ People's attitude towards predators is gradually changing - the awareness of a need to restore them to the environment has increased considerably. Regulation of herbivore population by predators helps protect deciduous plants and slows down climatic changes. ${ }^{99}$

Until recently, the issue of the legal character of an animal did not cause divergence in the doctrine and judicature. Animals were treated as movable things, the object of ownership and property rights. This concept was applied also to wild animals - if they were seized (taken possession of), they changed from things belonging to no one into objects. Scientific research has proven that animals experience pain, suffering and fear, are able to evaluate and to express emotions - they are legal goods of an exceptional character. Dereification of animals in the positive law has generated a number of problems, e.g., what an animal is from the legal perspective. Despite legislative initiatives undertaken and a multitude of potential methods and measures for the protection of animals living in the wild, the current concept of protection which consists is prevention of damage to the environment, undertaken in the interest of a man who frequently neglects nature, seems insufficient to safeguard the interests of animals living in the wild.

cepcje polityki, eds. I. Nurzyńska, M. Drygas, Warszawa 2011, pp. 195-218; K. Dubel, Przyrodnicze uwarunkowania w planowaniu przestrzennym, Białystok 1998, pp. 25-32.

97 S. Mroczkowski, A. Frieske, op. cit., pp. 63-78.

98 With respect to animals living in the wild, the legislator adopted various concepts of liability for damage, owing to the fact that two groups of animals: game and protected species are covered by the scope of liability. See M. Goettel, op. cit., pp. 357-384 and the literature cited therein.

${ }_{99}$ S. Mroczkowski, A. Frieske, op. cit., p. 6. 


\section{REFERENCES}

\section{Literature}

Białocerkiewicz J., Status prawny zwierząt. Prawa zwierząt czy prawna ochrona zwierząt, Torun 2005. Bisgould L., Animals and the Law, London 2011.

Bołtromiuk A., Kłodziński M., Polityka rozwoju obszarów cennych przyrodniczo, [in:] Rozwój obszarów wiejskich w Polsce. Diagnozy, strategie, koncepcje polityki, eds. I. Nurzyńska, M. Drygas, Warszawa 2011.

Bronowska K., Ochrona środowiska w prawodawstwie polskim - rys historyczny, "Ochrona Środowiska. Przegląd" 2002, no. 1.

Ciechanowicz J., Aktualne problemy prawa ochrony środowiska w Polsce, "Prawo i Środowisko" 1997, no. 5.

Ciszewska A, Zachowanie terenów cennych przyrodniczo w kształtowaniu struktury krajobrazu na poziomie miejscowego planu zagospodarowania przestrzennego, "Problemy Ekologii Krajobrazu" 2008, vol. 21.

Danecka D., Wybrane problemy funkcjonowania parków narodowych w Polsce, "Przegląd Prawa Ochrony Środowiska” 2015, no. 3, DOI: https://doi.org/10.12775/PPOS.2015.033.

Dubel K., Przyrodnicze uwarunkowania w planowaniu przestrzennym, Białystok 1998.

Eadie E.N., Understanding Animal Welfare, Berlin-Heidelberg 2012.

Gabriel-Węglowski M., Przestępstwa przeciwko humanitarnej ochronie zwierząt, LEX/el. 2009.

Godlewski S., Vademecum myśliwego, Warszawa 1955.

Goettel M., Sytuacja zwierzęcia w prawie cywilnym, Warszawa 2013.

Grabowska G., Europejskie prawo środowiska, Warszawa 2001.

Gruszecki K., Komentarz do ustawy o ochronie przyrody, Warszawa 2005.

Grzybowski S., [in:] System Prawa Cywilnego, vol. 1: Część ogólna, ed. S. Grzybowski, Wrocław 1985.

Habuda A., Konsekwencje prawne objęcia parku narodowego obszarem Natura 2000, [in:] Prawne aspekty gospodarowania zasobami środowiska. Korzystanie z zasobów środowiska, eds. B. Rakoczy, M. Szalewska, K. Karpus, Toruń 2014.

Habuda A., Wyznaczanie obszarów Natura 2000, [in:] idem, Obszary Natura 2000 w prawie polskim, Warszawa 2013.

Helios J., Jedlecka W., Administracyjnoprawne aspekty ochrony zwierzat, [in:] Aspekty prawne, filozoficzne i religijne ochrony roślin i zwierzą - wybrane zagadnienia, eds. J. Helios, W. Jedlecka, A. Ławniczak, Wrocław 2016.

Helios J., Jedlecka W., Zwierzęta w głównych religiach świata, [in:] Aspekty prawne, filozoficzne $i$ religijne ochrony roślin i zwierząt - wybrane zagadnienia, eds. J. Helios, W. Jedlecka, A. Ławniczak, Wrocław 2016.

Habuda A., Radecki W., Przepisy karne w ustawach o ochronie zwierząt oraz o doświadczeniach na zwierzętach, "Prokuratura i Prawo" 2008, no. 5.

Janik C., Status zwierzęcia w głównych systemach religijnych, [in:] Status zwierzęcia. Zagadnienia filozoficzne i prawne, eds. T. Gardocka, A. Gruszczyńska, Torun 2012.

Lebowa D., Podstawy prawne funkcjonowania parków krajobrazowych w Polsce, [in:] Administracja publiczna - człowiek a ochrona środowiska. Zagadnienia społeczno-prawne, eds. M. Górski, J. Bucińska, M. Niedziółka, R. Stec, D. Strus, Warszawa 2011.

Listos P., Dylewska M., Gryzińska M., Rys historyczny prawnych aspektów ochrony weterynaryjnej zwierzat w Polsce, "Przegląd Prawa i Administracji" 2017, no. 108,

DOI: https://doi.org/10.19195/0137-1134.108.9. 
Matecki T., Ochrona zwierząt w Polsce, Warszawa 1949.

Mazur E., Środowisko przyrodnicze. Zagrożenia, ochrona i ksztaltowanie, Szczecin 2004.

Mikosz R., Prawa do przedmiotów materialnych niebędacych rzeczami, [in:] System Prawa Prywatnego, vol. 4: Prawo rzeczowe, ed. E. Gniewek, Warszawa 2007.

Miłkowska J., Status prawny ryb wód śródlądowych a status prawny zwierząt łownych, "Ochrona Środowiska. Prawo i Polityka" 2008, no. 1.

Mroczkowski S., Frieske A., Prawna ochrona zwierząt wolno żyjacych, Warszawa 2017.

Pchałek M., Ochrona gatunkowa w procesie inwestycyjnym, [in:] Wybrane problemy prawa ochrony środowiska, eds. B. Rakoczy, M. Pchałek, Warszawa 2010.

Piątowski J.S., [in:] System prawa cywilnego, ol. 2: Prawo własności i inne prawa rzeczowe, ed. J. Ignatowicz, Wrocław 1977.

Przyborowska-Klimczak A., Ochrona przyrody. Studium prawnomiędzynarodowe, Lublin 2004.

Raba M., Karnoprawna ochrona zwierząt łownych, "Prokuratura i Prawo" 2010, no. 9.

Radecki W., Ochrona prawna parków narodowych przed zagrożeniami zewnętrznymi (na kilku przykładach z Ojcowskiego Parku Narodowego), "Prace i Materiały Muzeum im. Prof. Władysława Szaferaw Prądniku" 2007, no. 17.

Radecki W., Prawo towieckie. Komentarz, Warszawa 2005.

Radecki W., Ustawy o ochronie zwierząt. Komentarz, Warszawa 2015.

Radecki W., Zarys historii prawnej ochrony przyrody w Polsce, [in:] Prawne formy ochrony przyrody, ed. J. Sommer, Warszawa 1990.

Rudnicki S., [in:] Kodeks cywilny. Komentarz, vol. 1, Warszawa 1972.

Sakowicz E., Znaczenie zwierząt w religiach świata, "Forum Teologiczne" 2005, vol. 6.

Samsonowicz A., Łowiectwo w Polsce Piastów i Jagiellonów, Wrocław 1991.

Skowrońska-Bocian E., Komentarz do Kodeksu cywilnego, Warszawa 2000.

Skrocka J., Szczepański A., Prawo towieckie. Komentarz, Warszawa 1998.

Smaga Ł., Ochrona humanitarna zwierząt, Białystok 2010.

Sobczak J., Ochrona zwierząt w prawie karnym, [in:] Status zwierzęcia. Zagadnienia filozoficzne i prawne, eds. T. Gardocka, A. Gruszczyńska, Toruń 2012.

Sobieraj K., Administrowanie formami ochrony przyrody, "Roczniki Nauk Prawnych KUL" 2013, vol. 23(4).

Stec R., Tworzenie obwodów łowieckich. Podstawy prawne, "Przegląd Ustawodawstwa Gospodarczego" 2000 , no. 10.

Stec S., Prawo wykonywania polowania, "Przegląd Ustawodawstwa Gospodarczego" 1997, no. 10.

Stefaniuk M., Environmental Awareness in Polish Society with Respect to Natural Resources and Their Protection (Overview of Survey Research), "Studia Iuridica Lublinensia" 2021, vol. 30(2), DOI: http://dx.doi.org/10.17951/sil.2021.30.2.357-379.

Stelmasiak J., Lebowa D., Obszar specjalny w prawie ochrony przyrody - zagadnienia ogólne, [in:] Prawo ochrony przyrody. Stan obecny, problemy, perspektywy, eds. D. Kopeć, N. Ratajczyk, Łódź 2008.

Symonides E., Ochrona przyrody, Warszawa 2008.

Szachułowicz J., Problematyka prawna dzierżawy obwodów towieckich, "Przegląd Sądowy” 2002, no. 4.

Woleński J., Podmiotowość zwierząt w aspekcie filozoficznym, [in:] Status zwierzęcia. Zagadnienia filozoficzne i prawne, eds. T. Gardocka, A. Gruszczyńska, Torun 2012.

Wybór dokumentów do nauki prawa międzynarodowego, comp. K. Kocot, K. Wolfke, WrocławWarszawa 1978.

Zarosa U., Status moralny zwierząt, Warszawa 2016. 


\section{Legal acts}

Act of 18 April 1985 on inland fishing (Journal of Laws 2015, item 652).

Act of 13 October 1995 - Hunting Law (Journal of Laws 2015, item 2168).

Act of 21 August 1997 on the protection of animals (consolidated text, Journal of Laws 2020, item 638).

Act of 27 April 2001 - Environmental Protection Law (Journal of Laws 2019, item 1396).

Act of 22 June 2001 on genetically modified organisms (Journal of Laws 2007, no. 36, item 233, as amended).

Act of 18 December 2003 on health facilities for animals (Journal of Laws 2015, item 1047).

Act of 29 January 2004 on the Veterinary Inspection (Journal of Laws 2015, item 1482).

Act of 11 March 2004 on the protection of animal health and on combating infectious diseases of animals (Journal of Laws 2014, item 29).

Act of 16 April 2004 on the protection of nature (Journal of Laws 2020, item 55, as amended).

Act of 13 April 2007 on preventing and repairing damage to the environment (Journal of Laws 2007, no. 75 , item 493 , as amended).

Act of 29 June 2007 on the organization of farm animal breeding and reproduction (Journal of Laws 2007 , no. 133 , item 921).

Act of 19 December 2014 on sea fishing (Journal of Laws 2015, item 222).

Act of 20 July 2017 - Water Law (Journal of Laws 2018, item 2268).

Constitution of the Republic of Poland of 2 April 1997 (Journal of Laws 1997, no. 78, item 483, as amended).

Convention on International Trade in Endangered Species of Wild Fauna and Flora, drawn up in Washington on 3 March 1973 (supplemented with three Appendices) (Journal of Laws 1991, no. 27 , item 112).

Convention on the Conservation of Migratory Species of Wild Animals, signed in Bonn on 23 June 1979 (Journal of Laws 2003, no. 2, item 17).

Convention on the Protection of Forests and Game Birds of 1781.

Council Directive 79/409/EEC of 2 April 1979 on the conservation of wild birds, OJ EU L 103/1, 2.04.1979).

Council Directive 92/43/EEC of 21 May 1992 on the conservation of natural habitats and of wild fauna and flora (OJ EU L 206/7, 22.07.1992).

Declaration of the United Nations Conference on the Human Environment, adopted in Stockholm on 16 June 1972.

Directive 2009/147/EC of the European Parliament and of the Council of 30 November 2009 on the conservation of wild birds (OJ EU L 20/7, 26.01.2010).

Joint Declaration for the Protection of Birds Useful to Agriculture, signed on 19 March 1875 by Austria-Hungary and Italy.

Regulation of the Minister of Environment of 11 March 2005 on the list of game species (Journal of Laws 2005, no. 45, item 433).

Regulation of the Minister of Environment of 16 March 2005 on the establishment of hunting periods for game animals (Journal of Laws 2005, no. 48, item 459).

Regulation of the Minister of Environment of 18 April 2005 on the conditions and mode of issuing permits for game hunting with birds of prey (Journal of Laws 2005, no. 69, item 621).

Regulation of the Minister of Environment of 27 December 2005 on hunting permits (Journal of Laws 2004, no. 264, item 2209).

Regulation of the Minister of Environment of 16 December 2016 on the protection of species (Journal of Laws 2016, item 2183). 
Pobrane z czasopisma Studia Iuridica Lublinensia http://studiaiuridica.umes.pl Data: 26/04/2023 11:59:03

Regulation of the Minister of Environment of 1 August 2017 amending the regulation on the establishment of hunting periods for game animals (Journal of Laws 2017, item 1487).

Regulation of the President of the Republic of Poland of 22 March 1928 on the protection of animals (Journal of Laws 1932, no. 42, item 417, as amended).

\begin{abstract}
ABSTRAKT
Zwierzęta dzikie funkcjonują w określonych ekosystemach, sprzyjają zachowaniu równowagi biologicznej, a ich prawna ochrona sięga starożytności. Wątpliwości co do charakteru prawnego zwierząt wolno żyjących istniały na długo przed pojawieniem się w polskim prawodawstwie zasady dereifikacji. Judykatura stanęła na stanowisku, że choć zwierzętom nie można odmówić przymiotu dóbr materialnych, nie są one rzeczami. Przyjęcie takiego założenia prowadziło do wniosku, że prawo własności zwierząt nie przysługuje ani państwu, ani żadnemu innemu podmiotowi. Uzasadniano to brakiem możliwości poddania zwierzęcia wolno żyjącego władztwu człowieka. Problematyka prawnej ochrony zwierząt wolno żyjących, stanowiąca część materialnego prawa administracyjnego, uregulowana została w szeregu aktów prawa międzynarodowego, europejskiego i krajowego. Rodzaje i cele ochrony zwierząt wolno żyjących oraz metody ochrony gatunków zagrożonych są zróżnicowane.
\end{abstract}

Słowa kluczowe: prawna ochrona; zwierzęta wolno żyjące; zwierzęta dzikie; polskie prawodawstwo; dereifikacja; ochrona gatunków zagrożonych 